\title{
MENGEKSPLORASI VARIABEL PEMEDIASI HUBUNGAN PENDIDIKAN KEWIRAUSAHAAN DAN NIAT BERWIRAUSAHA SELAMA PANDEMI COVID-19
}

\author{
Nia Nur Safitri ${ }^{1}$, Jaka Nugraha ${ }^{2}$ \\ ${ }^{1}$ Universitas Negeri Surabaya, nianursafitri65@gmail.com \\ ${ }^{2}$ Universitas Negeri Surabaya, jakanugraha@unesa.ac.id
}

\section{DOI}

https://doi.org/10.26740/jupe.v10n1.p23$\underline{37}$

\author{
Article history \\ Received \\ 9 November 2021 \\ Revised \\ 20 November 2021 \\ Accepted \\ 22 November 2021
}

\section{How to cite}

Safitri, N. N., \& Nugraha, J. (2022). Mengeksplorasi Variabel Pemediasi Hubungan Pendidikan Kewirausahaan dan Niat Berwirausaha Selama Pandemi Covid-19. Jurnal Pendidikan Ekonomi (JUPE), 10(1), 23-37. https://doi.org/10.26740/jupe.v10n1.p23$\underline{37}$

Kata Kunci: pendidikan kewirausahaan, niat berwirausaha, risk taking, self efficacy, proactiveness

Keywords:entrepreneurship education, entrepreneurial intentions, risk taking, self efficacy, proactiveness

\section{Corresponding author}

Nia Nur Safitri

nianursafitri65@gmail.com

\begin{abstract}
Abstrak
Penelitian ini bertujuan untuk mengetahui pengaruh pendidikan kewirausahaan terhadap niat berwirausaha melalui risk taking, self efficacy, dan proactiveness selama pandemi covid-19. Populasi dalam penelitian ini adalah siswa kelas XI dan XII jurusan otomasi tata kelola perkantoran yang mengambil mata pelajaran produk kreatif dan kewirausahaan di SMKN 1 Surabaya dengan menggunakan 188 responden dengan teknik simple random sampling. Metode pengumpulan data menggunakan kuesioner. Analisis data yang digunakan dalam penelitian ini adalah Structural Equation ModellingPartial Least Square (SEM-PLS). Hasil yang diperoleh dalam penelitian ini adalah pendidikan kewirausahaan tidak berpengaruh secara signifikan terhadap niat berwirausaha, risk taking sebagai mediasi tidak berpengaruh signifikan antara pendidikan kewirausahaan dan niat berwirausaha, self efficacy mampu memediasi secara signifikan pengaruh pendidikan kewirausahaan terhadap niat berwirausaha, proactiveness tidak mampu memediasi secara signifikan pengaruh pendidikan kewirausahaan terhadap niat berwirausaha. Keterbatasan penelitian ini adalah model yang diusulkan hanya diujicobakan di SMKN 1 Surabaya, siswa kelas XI dan XII jurusan otomasi tata kelola perkantoran. Orisinalitas dalam penelitian ini adalah untuk mengukur variabel pemediasi yaitu risk taking, self efficacy, dan proactiveness dalam hubungan antara pendidikan kewirausahaan dan niat berwirausaha.
\end{abstract}

Abstract
This study aims to determine the effect of entrepreneurship education
on entrepreneurial intentions through risk taking, self-efficacy, and
being proactive during the COVID-19 pandemic. The population in
this study were students of class XI and XII majoring in office
governance automation who took lessons on creative products and
entrepreneurship at SMKN 1 Surabaya using 188 respondents with
simple random sampling technique. Methods of data collection using
a questionnaire. Analysis of the data used in this study is Structural
Equation Modeling-Partial Least Square (SEM-PLS). The results
obtained in this study are entrepreneurship education has no significant
effect on entrepreneurial intentions, risk taking as a mediation has no
significant effect between entrepreneurship education and
entrepreneurial intentions, self-efficacy is able to significantly mediate
the effect of entrepreneurship on entrepreneurial intentions, proactive
is not able to significantly mediate the effect of education
entrepreneurship to entrepreneurial intentions. The limitation of this
study is that the proposed model was only tested in SMKN 1 Surabaya,
students of class XI and XII majoring in office governance automation.
Originality in this study is to measure the mediating variables, namely
risk taking, self-efficacy, and proactiveness in the relationship between
entrepreneurship education and entrepreneurial intentions.




\section{PENDAHULUAN}

Pengangguran merupakan salah satu masalah yang ada di Indonesia. Karena negara Indonesia saat ini merupakan salah satu negara yang memiliki tingkat pengangguran yang cukup tinggi. Hal ini dikarenakan kuantitas pada tenaga kerja dan peluang kerja di Indonesia yang tersedia tidak seimbang. Karena bertambah banyaknya angkatan kerja maka kesempatan kerja sangatlah sedikit. Sehingga menyebabkan permasalahan lain yaitu seperti kemiskinan, kriminalitas, dan kesenjangan sosial (Adnyana \& Purnami, 2016).

Tingkat pengangguran terbuka (TPT) di Indonesia pada bulan Februari 2021 mencapai 6,26\%. TPT tersebut meningkat $1,32 \%$ poindibandingkan pada bulan Februari 2020 yang sebesar 4,99\%. Badan Pusat Statistik mencatat tingkat pengangguran yang berada di Indonesia pada bulan Februari 2021 berjumlah 8,75 juta orang. Jumlah tersebut meningkat daripada bulan Februari 2020 yang berjumlah 6,93 juta (Badan Pusat Statistik, 2021). Kenaikan jumlah pengangguran yang semakin meningkat secara signifikan ini dikarenakan adanya pandemi covid19. Tamatan Sekolah Menengah Kejuruan masih termasuk dalam kategori tingkat pengangguran yang paling tinggi daripada lulusan jenjang pendidikan yang lain yaitu berjumlah $11,45 \%$. Dan tingkatan pengangguran yang paling rendah merupakan tingkatan pada pendidikan Sekolah Dasar (SD) ke bawah dengan jumlah 3,13\% (Badan Pusat Statistik, 2021).

Adanya pandemi covid-19 saat ini, mengakibatkan pada angka pengangguran di Indonesia semakin meningkat. Karena pada sektor ketenagakerjaan selama pandemi covid-19 di Indonesia ini memberikan pengaruh yang cukup besar. Pandemi covid-19 ini mengakibatkan sejumlah perusahaan di Indonesia mengalami rasionalisasi dengan menekan biaya operasional pada perusahaan, sehingga mengakibatkan pengurangan tenaga kerja.

Tingginya angka kenaikan pada tingkat pengangguran di Indonesia yang secara terus menerus terlihat jelas adanya ketimpangan terhadap jumlah lapangan pekerjaan yang ada di Indonesia dengan potensi manusia. Oleh karena itu munculnya beberapa masalah mengenai pengangguran setiap tahunnya. Berdasarkan hal tersebut terbentuk suatu cara yang dilakukan oleh pemerintah dengan memberikan suatu solusi pada setiap intansi di Sekolah Menengah Kejuruan dengan memberikan pengalaman serta pembekalan yang berguna untuk mencetak lulusan pada Sekolah Menengah Kejuruan yang mampu memiliki jiwa wirausaha.

Lulusan Sekolah Menengah Kejuruan sudah mendapatkan keterampilan serta pengetahuan yang lebih mahir dibandingkan lulusan lainnya, seharusnya lulusan tingkat Sekolah Menengah Kejuruan ini lebih mudah dalam mendapatkan pekerjaan. Akan tetapi, yang terjadi dalam angka tingkat pengangguran terbuka di Indonesia memberikan hasil bahwa Sekolah Menengah Kejuruan merupakan tingkat pengangguran tertinggi. Hal tersebut dapat terjadi karena di Indonesia penyedia lapangan pekerjaan sedikit, sedangkan jumlah pada lulusan Sekolah Menengah Kejuruan lebih tinggi dari penyedia lapangan pekerjaan tersebut. Oleh karena itu siswa lulusan Sekolah Menengah Kejuruan diharapkan memiliki mutu yang tinggi dalam memberikan keterampilan agar dapat membuka lapangan pekerjaan sendiri atau berwirausaha.

Faktor angka pengangguran di Indonesia meningkat disebabkan karena banyaknya tenaga kerja di Indonesia yang tidak berusaha untuk memulai berwirausaha atau membuka lapangan pekerjaan untuk usaha sendiri, sehingga pengangguran di Indonesia semakin meningkat sampai saat ini. Hal tersebut disebabkan oleh preferensi seseorang yang memilih untuk berkerja di bidang sektor formal dari pada memilih untuk menjadi seorang pengusaha. Oleh karena itu semakin tingginya tingkat pengangguran yang ada di Indonesia, maka semakin tinggi pula tingkat kemiskinan di Indonesia (Anggraeni \& Nurcaya, 2016).

Masalah pada pengangguran yang terjadi saat ini dapat diatasi dengan cara berwirausaha serta menjadikan pengusaha adalah salah satu cara yang benar dalam mengatasi sebuah pengangguran yang saat ini. Wirausaha dapat diartikan sebagai salah satu upaya untuk menentukan kemajuan dalam perekonomian di Indonesia saat ini. Selain itu, berwirausaha juga dapat menjadikan pendorong untuk suatu kemandirian pada bangsa, serta dapat ditingkatkan pada diri siswa sebagai generasi penerus bangsa. Berwirausaha merupakan pilihan untuk mengatasi permasalahan mengenai pengangguran yang semakin meningkat. Namun untuk memulai berwirausaha kebanyakan masyarakat takut untuk memulainya, dikarenakan mereka tidak memiliki keyakinan diri untuk mendirikan suatu usaha tersebut serta tidak berani menanggung risiko yang akan terjadi. Maka penting adanya pendidikan kewirausahaan di seluruh jenjang pendidikan, utamanya di Sekolah Menengah Kejuruan (SMK). Sehingga dalam hal ini pemerintah memiliki program kewirausahaan untuk mengatasi pengangguran.

Sekolah Menengah Kejuruan (SMK) adalah tingkat pendidikan menengah yang memberikan lulusan pada siswanya agar dapat menjadikan tenaga kerja yang memiliki keterampilan, produktif, serta kreatif, sehingga mampu meningkatkan sikap professional pada siswa yang didapat oleh bidangnya. Siswa yang sedang melaksanakan pendidikannya di SMK harus mempersiapkan keterampilannya agar dapat membuat peluang usaha yang akan dipergunakan untuk memulai bisnisnya, siswa SMK 
dalam pendidikannya tidak hanya dapat bekerja pada peluang kerja yang ada dalam industri saja, akan tetapi adanya sebuah pendidikan yang didapatkan oleh siswa SMK, maka lulusan siswa SMK harus dapat memiliki jiwa berwirausaha serta perilaku dalam berwirausaha.

Pendidikan kewirausahaan adalah salah satu faktor penting yang digunakan untuk mengukur tingkat kemampuan siswa dalam berwirausaha. Menurut Abbassi \& Sta (2019) bahwa tujuan pendidikan kewirausahaan adalah untuk membekali siswa dengan kreativitas dan keterampilan dalam berwirausaha. Oleh karena itu, siswa dilatih untuk mengembangkan kewirausahaannya. Dengan adanya pendidikan kewirausahaan nantinya akan menumbuhkan niat berwirausaha pada diri siswa. Pendidikan kewirusahaan adalah segala aktivitas yang memiliki tujuan untuk menumbukan pemikiran serta mindset mengenai wirausaha pada diri siswa, meningkatkan niat, sikap, serta keterampilan pada diri seseorang untuk meningkatkan potensi yang dimilikinya dengan cara melaksanakan perilaku yang berketerampilan kreatif serta inovatif (Indriyani, 2017). Secara konseptual pendidikan kewirausahaan merupakan suatu proses yang memiliki tujuan untuk melengkapi individu dengan konsep serta keterampilan yang berguna untuk mengetahui peluang bisnis, serta memberikan kepercayaan pada diri seseorang agar dapat berperan dalam peluang bisnis tersebut.

Pentingnya pendidikan kewirausahaan ini juga didasari pada beberapa hal penting, yaitu dapat memberikan rasa keyakinan diri dalam berwirausaha, melalui pendidikan kewirausahaan siswa diharapkan berani untuk mengambil risiko dalam berwirausaha serta mencari peluang dan menemukan ide-ide bisnis baru yang akan digunakan dalam berwirausaha. Pendidikan kewirausahaan diciptakan agar siswa dapat memberikan sebuah gambaran dalam berwirausaha, serta dapat meningkatkan niat berwirausaha siswa. Intention merupakan syarat dasar pada diri seseorang untuk memulai berwirausaha. Karena niat berwirausaha dapat diartikan sebagai syarat dasar seseorang untuk menjadi pengusaha.

Niat berwirausaha merupakan faktor utama yang harus diperhatikan untuk mengetahui suatu proses dalam melaksanakan wirausaha yang memiliki tujuan untuk membuka usaha baru, serta komitmen yang ada pada diri seseorang yang berguna untuk berwirausaha. Seseorang yang memiliki tingkat niat berwirausaha yang tinggi, maka akan lebih mudah untuk memulai usahanya dibandingkan seseorang yang tidak memiliki intensi dalam berwirausaha. Karena niat berwirausaha adalah langkah awal seseorang yang bertujuan untuk suatu proses pendirian guna memulai berwirausaha. Menurut Rasli et al. (2013), Niat kewirausahaan dapat diartikan sebagai salah satu pikiran yang dapat memberikan dorongan pada seseorang untuk menciptakan suatu usaha yang baru. Niat berwirausaha dapat diartikan juga sebagai pikiran seseorang yang memberikan arah perhatian untuk berwirausaha sendiri daripada atas nama orang lain (Abbassi \& Sta, 2019). Menurut Indriyani (2017) niat berwirausaha merupakan suatu keyakinan seseorang bahwa karir dalam berwirausaha adalah pilihan alternatif yang terbaik untuk dirinya, sehingga dengan memilih berwirausaha sebagai pilihannya, maka pilihan tersebut dapat mengarahkan pada kegiatan yang memiliki tujuan untuk mencipatakan sebuah usaha. Intensi berwirausaha merupakan faktor yang penting dalam mewujudkan pengetahuan yang sudah didapatkan siswa serta keterampilan dalam berwirausaha.

Tujuan utama pendidikan kewirausahaan adalah niat berwirausaha. Karena pendidikan kewirausahaan dapat memberikan pengetahuan tentang berwirausaha, dan niat berwirausaha merupakan syarat dasar untuk menjadi seorang entrepreneur (Keat et al., 2011).

SMKN 1 Surabaya adalah salah satu sekolah menengah kejuruan yang mampu memberikan peluang untuk berwirausaha kepada siswanya. Berdasarkan hasil observasi di SMKN 1 Surabaya melalui wawancara dengan Ibu Dra. Dwi Sudarwati selaku guru mata pelajaran produk kreatif dan kewirausahaan menyatakan bahwa adanya pendidikan produk kreatif dan kewirausahaan di SMKN 1 Surabaya jurusan otomatisasi tata kelola perkantoran sebagai mata pelajaran wajib yang harus dilaksanakan pada siswa kelas XI dan XII dapat memberikan pelatihan terhadap kreativitas pada siswa dengan membuat suatu produk yang akan dijual. Mata pelajaran mengenai kewirausahaan tersebut bertujuan untuk mencetak lulusan menjadi seorang wirausaha. Akan tetapi, tidak sedikit pula seorang siswa yang memiliki keinginan untuk berwirausaha tetapi belum berani dalam mengambil risiko yang akan dihadapi oleh siswa. Dan tidak semua siswa yang sudah menerima pendidikan produk kreatif dan kewirausahaan memiliki keinginan untuk menjadi seorang entrepreneur. Disebabkan karena banyaknya risiko yang akan dihadapi. Dengan adanya hal tersebut, maka SMKN 1 Surabaya memberikan beberapa program bagi siswanya agar terbiasa dalam berwirausaha, antara lain yaitu business center yang merupakan suatu tempat untuk melakukan wirausaha yang berguna untuk menunjang kompetensi keahlian siswa dalam bidang kewirausahaan. Selain itu juga terdapat lomba mengenai kewirausahaan yaitu seperti business plan yang merupakan suatu kegiatan yang bertujuan untuk mengasah kompetensi berwirausaha yang berada dalam diri siswa. Melaui beberapa progaram tersebut, SMKN 1 Surabaya memiliki tujuan untuk mencetak lulusannya menjadi seseorang yang memiliki jiwa wirausaha. Hal yang 
penting untuk menjadi seorang wirausaha yaitu memiliki niat, kemampuan, berani mengambil risiko, bekerja keras, serta mampu mencari ide yang baru untuk persaingan bisnis. Dalam meningkatkan jumlah lulusan Sekolah Menengah Kejuruan (SMK) yang memiliki jiwa wirausaha, maka dengan adanya pendidikan kewirausahaan tersebut dapat memberikan pembentukan serta penguatan pada diri siswa agar dapat meningkatkan niat untuk menjadi seorang wirausaha.

Risk Taking merupakan suatu keinginan untuk meraih peluang usaha yang kemungkinan juga dapat menyebabkan suatu kerugian dalam berwirausaha. Risk Taking juga dapat diartikan sebagai pengambilan risiko dalam berwirausaha. Dalam berwirausaha banyak hal yang harus dimiliki oleh seorang entrepreneur, salah satunya yaitu berani mengambil risiko yang akan terjadi. Siswa SMKN 1 Surabaya pendidikan produk kreatif dan kewirausahaan, dengan adanya pendidikan tersebut diharapkan siswa SMKN 1 Surabaya berani dalam mengambil risiko untuk memulai berwirausaha.

Self Efficacy dapat diartikan sebagai kepercayaan atau keyakinan diri seseorang atas kemampuan dirinya yang memiliki tujuan untuk sukses dalam melakukan sesuatu. Self Efficacy merupakan salah satu faktor penting untuk memulai berwirausaha, karena dengan adanya Self Efficacy tersebut, seseorang yakin bahwa dirinya akan sukses dalam berwirausaha. Hal tersebut harus dimiliki dalam diri siswa, maka dari itu SMKN 1 Surabaya dengan mendapatkan mata pelajaran produk kreatif dan kewirausahaan, siswanya diharapkan memiliki sikap untuk yakin dan percaya untuk sukses dalam berwirausaha. Oleh karena itu akan menumbuhkan intensi dalam berwirausaha pada diri siswa.

Proactiveness merupakan suatu sikap pada diri seseorang yang memiliki inisiatif untuk memecahkan suatu masalah dalam menciptakan sesuatu yang baru atau mencari ide yang baru. Proactiveness juga dapat diartikan sebagai pencarian sebuah peluang usaha secara terus menerus. Proactiveness juga merupakan faktor yang penting dalam berwiruasaha, karena adanya proactiveness dalam berwirausaha dapat menciptakan ide yang baru untuk memulai berwirausaha, serta mencari peluang dalam berwirausaha. Siswa SMKN 1 Surabaya dengan mendapatkan pendidikan produk kreatif dan kewirausahaan, siswanya diharapkan dapat mencari ide baru untuk memulai berwirausaha, serta mampu mencari peluang usaha. Oleh karena itu adanya faktor proactiveness diharapkan mampu menumbuhkan intensi dalam berwirausaha pada diri siswa.

Pada penelitian sebelumnya sudah banyak peneliti yang meneliti pengaruh pendidikan kewirausahaan terhadap niat berwirausaha (Devi \& Hadi, 2018). Penelitian Mahendra et al. (2017) menemukan hasil bahwa pendidikan kewirausahaan tidak secara langsung berpengaruh terhadap niat berwirausaha. Dalam penelitian Al Habib \& Rahyuda (2015) juga meneliti pengaruh keberanian pengambilan risiko terhadap niat berwirausaha. Hasil penelitian Mustofa \& Ekawati (2017) menujukkan hasil bahwa pengambilan risiko sebagai variabel mediasi tidak ada pengaruh secara signifikan terhadap niat berwirausaha. Sudah banyak juga peneliti yang meneliti peran self efficacy sebagai variabel mediasi dari pengaruh pendidikan kewirausahaan terhadap niat berwirausaha (Lestari \& Sukirman, 2020). Dalam penelitian Sudjarwo et al. (2019) juga memberikan hasil pada penelitiannya bahwa self efficacy memediasi hubungan secara signifikan pengaruh pendidikan kewirausahaan terhadap niat berwirausaha. Dalam penelitian Adu et al. (2020) juga meneliti tentang pengaruh pendidikan kewirausahaan terhadap niat berwirausaha melalui proactiveness sebagai variabel mediasi. Akan tetapi masih belum ada peneliti yang meneliti tentang mengeksplorasi variabel pemediasi hubungan pendidikan kewirausahaan dan niat berwirausaha selama pandemi covid-19. Pada variabel mediasi dalam penelitian ini memiliki peran yang sangat penting dalam hubungan pendidikan kewirausahaan dan niat berwirausaha. Pada peran variabel mediasi risk taking pada penelitian ini yaitu keberanian pengambilan risiko dalam berwirausaha akan muncul apabila seseorang mendapatkan pengalaman serta pengetahuan tentang pendidikan kewirausahaan, karena semakin tinggi pengalaman dan pengetahuan seseorang tentang wirausaha maka akan membuat seseorang berani dalam pengambilan risiko untuk berwirausaha. Peran variabel mediasi self efficacy pada penelitian ini yaitu keyakinan akan diri sendiri untuk berwirausaha akan muncul apabila seseorang mendapatkan wawasan mengenai pendidikan kewirausahaan, karena semakin tinggi wawasan seseorang tentang wirausaha maka akan membuat seseorang tersebut bergerak, mengamati, dan mengidentifikasi peluang usaha. Variabel mediasi proactiveness pada penelitian ini juga memiliki peran yang penting yaitu pencarian peluang aktif pada diri seseorang akan muncul apabila mendapatkan pengetahuan mengenai pendidikan kewirausahaan, karena semakin tinggi pengetauan pendidikan kewirausahaan serta pengalaman dalam wirausaha maka akan membuat seseorang tersebut bergerak guna mencari peluang aktif untuk berwirausaha. Hal tersebut merupakan kesenjangan dalam penelitian ini. Adapun tujuan dari penelitian ini antara lain yaitu: (1) Untuk mengetahui apakah pendidikan kewirausahaan berpengaruh terhadap niat berwirausaha selama pandemi covid-19, (2) Untuk mengetahui apakah ada pengaruh pendidikan kewirausahaan terhadap niat berwirausaha melalui risk taking selama pandemi covid- 
19, (3) Untuk mengetahui apakah ada pengaruh pendidikan kewirausahaan terhadap niat berwirausaha melalui self efficacy selama pandemi covid-19, (4) Untuk mengetahui apakah pengaruh pendidikan kewirausahaan terhadap niat berwirausaha melalui proactiveness selama pandemi covid-19.

Penelitian ini akan dilakukan pada siswa jurusan Otomatisasi Tata Kelola Perkantoran kelas XI dan XII yang telah menempuh pendidikan Produk Kreatif dan Kewirausahaan. Oleh karena itu, adanya pendidikan tersebut diharapkan dapat memberikan niat berwirausaha pada diri siswa untuk memilih berwirausaha sebagai karirnya. Dengan adanya hal tersebut, maka peneliti ingin mengetahui seberapa besar pengaruh Pendidikan kewirausahaan terhadap Niat berwirausaha melalui Risk Taking, Self Efficacy, dan Proactiveness sebagai variabel intervening.

\section{Pengaruh Pendidikan Kewirausahaan dengan Niat Berwirausaha}

Pendidikan kewirausahaan adalah segala aktivitas pembelajaranyang memiliki tujuan untuk meningkatkan pemikiran serta mindset seseorang terhadap wirausaha pada diri siswa, meningkatkan niat, sikap, serta keterampilan pada diri seseorang untuk meningkatkan potensi yang dimilikinya dengan cara melaksanakan perilaku yang berketerampilan kreatif serta inovatif dan berani dalam pengambilan risiko. Menurut Wardani \& Nugraha (2021) Pendidikan Kewirausahaan adalah wadah dalam suatu proses belajar serta mengenalkan kepada siswa tentang pengetahuan dan ilmu kewirausahaan. pendidikan kewirausahaan adalah salah satu disiplin ilmu yang mendalami tentang nilai, keahlian serta sikap agar dapat mengahadapi sebuah proses kehidupan (Aryaningtyas \& Palupiningtyas, 2017). Menurut Lekoko et al. (2012), bahwa pendidikan kewirausahaan dapat diartikan sebagai suatu hal yang cukup penting untuk mengembangkan keterampilan, sikap serta perilaku kewirausahaan yang akan menjadikan salah satu faktor penting yang berguna untuk meningkatkan ekonomi dalam suatu negara. Berikut merupakan tujuan dari pendidikan kewirausahaan ini antara lain yaitu: (1) memberikan pengetahuan serta kesadaran dalam berwirausaha, (2) memberikan kesadaran yang tinggi bahwa berwirausaha dijadikan sebagai pilihan karir untuk masa depan, (3) meningkatkan efikasi diri dalam berwirausaha. Oleh karena itu, sebagai lembaga pendidikan utamanya pada sekolah menengah kejuruan memiliki peran yang sangat penting untuk meningkatkan motivasi mengenai kegunaan serta keuntungan yang ada dalam wirausaha.

Pendidikan kewirausahaan merupakan suatu hal yang penting dalam mendorong kewirausahaan, Salah satunya adalah pendidikan kewirausahaan dapat meningkatnya rasa kemandirian serta rasa percaya diri pada individu dalam memungkinkan pengenalan sebagai pilihan karir alternatif, maka melalui pendidikan kewirausahaan seorang individu diharapkan agar dapat meningkatkan wawasan dan pengetahuan mengenai kewirausahaan yang akan dipergunakan untuk meningkatkan peluang usaha baru di masa mendatang (Dogan, 2015). Berdasarkan definisi tersebut dapat memberikan gambaran bahwa dengan adanya pendidikan kewirausahaan, maka akan dapat meningkatkan niat seseorang untuk melakukan wirausaha.

Kurikulum SMKN 1 Surabaya yang memuat mata pelajaran produk kreatif kewirausahaan dapat memberikan pembelajaran pada siswa dengan mencari peluang usaha dan juga merencanakan produk usaha. Sehingga dengan adanya hal tersebut dapat memberikan motivasi terhadap siswa mengenai wirausaha. Dalam mata pelajaran produk kreatif kewirausahaan ini memberikan kompetensi inti pada siswa agara dapat memahami, menerapkan, menganalisis dan mengevaluasi tentang wirausaha, sehingga siswa mampu menumbuhkan niat untuk berwirausaha. Hasil dari penelitian Abbassi \& Sta (2019) menunjukkan bahwa pendidikan kewirausahaan berpengaruh secara positif serta siginifikan terhadap niat berwirausaha. Pendidikan kewirausahaan merupakan salah satu hal yang sangat penting yang berguna dalam memberikan dorongan minat pada diri seseorang untuk berwirausaha (Aryaningtyas \& Palupiningtyas, 2017). Devi \& Hadi (2018) dalam penelitiannya juga menunjukkan hasil bahwa terdapat pengaruh positif dan signifikan antara pendidikan kewirausahaan terhadap intensi berwirausaha.

Hasil penelitian Otache et al. (2019) mengungkapkan bahwa pendidikan kewirausahaan memberika pengaruh positif serta signifikan terhadap niat berwirausaha yang ada pada diri siswa. Semakin tinggi tingkat pendidikan kewirausahaan, maka semakin meningkat pula intensi berwirausaha pada diri siswa. Penelitian Indriyani (2017) juga memberikan hasil bahwa pendidikan kewirausahaan memberikan pengaruh positif serta signifikan terhadap niat berwirausaha. Pendidikan kewirausahaan memiliki peran yang sangat penting untuk menunjang wirausaha, karena dengan adanya pendidikan kewirausahaan akan menumbuhkan niat berwirausaha pada diri siswa. Berdasarkan hasil riset terdahulu maka hipotesis yang diajukan adalah:

$\mathrm{H}_{1}$ : Pendidikan kewirausahaan berpengaruh positif signifikan terhadap niat berwirausaha 
Pengaruh Pendidikan Kewirausahaan dengan Niat Berwirausaha melalui Risk Taking sebagai Variabel Mediasi

Risk taking adalah keinginan pada diri seseorang dalam meraih sebuah peluang usaha, akan tetapi kemungkinan menimbulkan kerugian pada usaha. Risk taking merupakan sikap berani dalam menghadapi sebuah tantangan yang kemungkinan hasilnya penuh ketidak pastian (Ranto, 2016). Risiko bagi seorang wirausaha bukanlah sebagai suatu hambatan untuk kesuksesan dalam berwirausaha, akan tetapi dijadikan suatu tantangan dalam berwirausaha. Wirausaha adalah seseorang yang lebih menyukai suatu tantangan untuk lebih mencapai dalam kesuksesan hidupnya.

Risk taking sangat diperlukan dalam menjalankan wirausaha. Dengan adanya pendidikan kewirausahaan di SMKN 1 Surabaya mata pelajaran produk kreatif kewirausahaan tersebut dapat mendorong siswa dalam menghadapi sebuah risiko untuk meraih peluang dalam berwirausaha. Hal ini didukung pada penelitian Adu et al. (2020) yang memberikan hasil bahwa risk taking sebagai mediasi mampu memberikan pengaruh positif serta siginifikan antara pendidikan kewirausahaan terhadap niat berwirausaha. Al Habib \& Rahyuda (2015) mengungkapkan bahwa keberanian pengambilan risiko sebagai variabel intervening mampu memediasi secara positif serta signifikan terhadap niat berwirausaha.

Melalui dorongan risk taking maka dapat berpengaruh terhadap pendidikan kewirausahaan yang kemudian meningkatkan niat berwirausaha (Bergner et al., 2021). Pada penelitian Gurel et al. (2010) dan (Hermawan \& Fitria (2020) juga mengungkapkan bahwa melalui risk taking maka pendidikan kewirausahaan berpengaruh positif terhadap niat berwirausaha. Berdasarkan hasil riset terdahulu maka hipotesis yang diajukan adalah:

$\mathrm{H}_{2}$ : Risk taking mampu memediasi secara positif signifikan hubungan antara pendidikan kewirausahaan terhadap niat berwirausaha

\section{Pengaruh Pendidikan Kewirausahaan dengan Niat Berwirausaha melalui Self Efficacy sebagai Variabel Mediasi}

Self Efficacy adalah faktor penting dalam membentuk kesiapan berwirausaha yang berasal dari dalam diri seseorang. Efikasi atau keyakinan diri merupakan suatu kepercayaan bahwa seorang individu mampu dan bisa melakukan sesuatu. Menurut Lestari \& Sukirman (2020) Self Efficay merupakan keyakinan pada diri seseorang atas kemampuan yang dimilikinya yang bertujuan agar dapat menyelesaikan suatu pekerjaan yang dilakukannya dalam berwirausaha. Self Efficacy adalah salah satu faktor yang penting yang ada pada diri seseorang yang dapat memberikan persiapan untuk memulai berwirausaha, serta keterampilan dan pengetahuan mengenai kewirausahaan (Apiatun \& Prajanti, 2019). Self Efficacy merupakan suatu keyakinan seseorang terhadap kemampuan pada dirinya untuk suatu pekerjaan agar dapat terselesaikan (Zulkosky, 2009). Efikasi atau keyakinan diri merupakan suatu kepercayaan seorang individu dapat dan bisa melakukan sesuatu. Definisi tersebut dapat memberikan gambaran bahwa dengan adanya Self efficacy dapat memberikan suatu kepercayaan dan keyakinan diri seseorang bahwa dirinya akan sukses dalam melakukan suatu tujuan tertentu.

Siswa SMKN 1 Surabaya dengan mengikuti mata pelajaran produk kreatif kewirausahaan mampu menemukan ide baru untuk mencari peluang usaha. Hal tersebut dapat diartikan bahwa siswa memiliki keyakinan diri untuk menciptakan suatu produk untuk berwirausaha. Hasil dari penelitian Agusmiati \& Wahyudin (2019) menunjukkan hasil bahwa self efficacy sebagai variabel moderating mampu memoderasi secara signifikan pengaruh pengetahuan dalam berwirausaha terhadap niat berwirausaha pada diri siswa. Dengan adanya self efficacy sebagai variabel mediasi, maka pendidikan kewirausahaan memiliki pengaruh positif serta signifikan hubungan antara pendidikan kewirausahaan dan niat berwirausaha (Anggraeni \& Nurcaya, 2016).

Apiatun \& Prajanti (2019) dalam penelitiannya juga menunjukkan hasil bahwa self efficacy sebagai variabel mediasi memberikan bukti bahwa variabel tersebut memberikan pengaruh yang kuat terhadap pengetahuan kewirausahaan dan kesiapan berwirausaha pada diri siswa. Pada hasil penelitian Lestari \& Sukirman (2020) dan Sudjarwo et al. (2019) mengungkapkan bahwa peran self efficacy masuk pada bagian yang sangat baik, serta self efficacy dapat memediasi pengaruh pendidikan kewirausahaan terhadap niat berwirausaha siswa. Berdasarkan hasil riset terdahulu maka hipotesis yang diajukan adalah:

$\mathrm{H}_{3}$ : Self efficacy mampu memediasi secara positif signifikan hubungan antara pendidikan kewirausahaan terhadap niat berwirausaha

\section{Pengaruh Pendidikan Kewirausahaan dengan Niat Berwirausaha melalui Proactiveness sebagai Variabel Mediasi}

Proactiveness dapat diartikan sebagai aktivitas dalam mencari sebuah peluang usaha secara menerus serta bereksperimen dengan cara menggunakan respon yang potensial terhadap kecenderungan seseorang pada perubahan lingkungan (Venkatraman, 1989). Proactiveness merupakan salah satu usaha dalam pencarian peluang, serta perspektif dengan memberikan pandangan ke depan yang bertujuan untuk pengenalan produk atau jasa baru yang berguna untuk bersaing serta 
bertindak untuk mengantisipasi permintaan di masa yang akan datang (Lumpkin \& Dess, 1996). Berdasarkan definisi tersebut proaktif merupakan suatu tindakan yang lebih aktif dalam mencari sebuah peluang, sikap proaktif ini sangat penting dalam melakukan berwirausaha, karena mampu mencari sebuah peluang yang ada.

Proactiveness sangat diperlukan dalam berwirausaha. Siswa SMKN 1 Surabaya dalam mengikuti mata pelajaran produk kreatif kewirausahaan mampu mencari peluang untuk memulai suatu usaha, serta menemukan ide-ide yang baru yang akan digunakan dalam berwirausaha. Hasil dari penelitian Adu et al. (2020) memberikan hasil bahwa proactiveness sebagai mediasi mampu memberikan pengaruh positif serta siginifikan antara pendidikan kewirausahaan terhadap niat berwirausaha. Aryaningtyas \& Palupiningtyas (2019) dalam penelitiannya juga memberikan hasil bahwa proactiveness secara positif serta signifikan memiliki pengaruh terhadap niat berwirausaha.

Dengan adanya faktor proactiveness mampu memediasai sepenuhnya terhadap intensi berwirausaha (Hu et al., 2018). Dalam penelitian Yasira et al. (2020) juga memberikan hasil bahwa proactiveness sebagai variabel mediasi dapat memberikan pengaruh sangat baik terhadap niat berwirausaha. Hasil penelitian Geubrina \& Megawati (2019) juga memberikan hasil bahwa proactiveness memberikan pengaruh yang positif serta signifikan terhadap niat berwirausaha. Proactiveness merupakan faktor yang penting dalam berwirausaha, semakin tinggi tingkat proactiveness siswa, maka semakin tinggi pula siswa dalam mencari sebuah peluang untuk memulai berwirausaha. Berdasarkan hasil riset terdahulu maka hipotesis yang diajukan adalah:

$\mathrm{H}_{4}$ : Proactiveness mampu memediasi secara positif signifika hubungan antara pendidikan kewirausahaan terhadap niat berwirausaha

Dari penjelasan diatas, maka kerangka konsep pada penelitian ini yaitu:

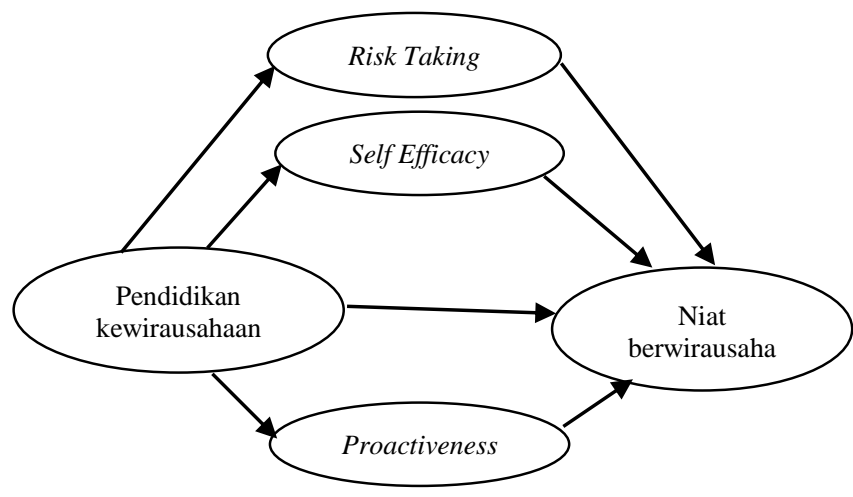

Gambar 1 : Kerangka konseptual

\section{METODE}

Penelitian ini menggunakan pendekatan kuantitatif, dimana pendekatan pada penelitian ini memakai data yang berupa angka-angka hasil jawaban survey lalu disebarkan ke populasi atau sampel penelitian serta dianalisis menggunakan teknik analisis statistik (Sugiyono, 2017).

Lokasi pada penelitian ini yaitu bertempat di SMKN 1 Surabaya. Pada pengambilan populasi dalam penelitian ini yaitu siswa jurusan Otomatisasi Tata Kelola Perkantoran SMKN 1 Surabaya yang sedang menempuh pendidikan Produk Kreatif dan Kewirausahaan sebagai mata pelajaran kelas XI dan XII. Dalam menentukan sampel pada penelitian ini menggunakan teknik probability sampling dengan menggunakan simple random sampling. Teknik tersebut dikatakan simple (sederhana) karena pengambilan anggota sampel dari populasi menggunakan cara acak yaitu tanpa memperhatikan strata yang ada dalam populasi tersebut (Sugiyono, 2017). dalam menentukan besaran sampel pada penelitian ini memakai rumus slovin, maka peneliti menggunakan rumus sebagai berikut :

$$
\begin{aligned}
& \mathrm{n}=\frac{\mathrm{N}}{1+\mathrm{Ne}^{2}} \quad \begin{array}{c}
\mathrm{n}: \text { jumlah sampel } \\
\mathrm{N}: \text { jumlah populasi } \\
\mathrm{n}=\frac{355}{1+355.5 \% \%^{2}}
\end{array} \\
& \mathrm{n}=\frac{355}{1+0,8875}=188 \text { sampel } \\
& \text { kesalahan (error) }
\end{aligned}
$$

Rumus perhitungan sampel dapat diketahuai jumlah sampel sebanyak 188. Penulis menggunakan kuisioner (angket) sebagai metode pengumpulan data yang digunakan pada penelitian ini, kuisioner tersebut berisi 5 variabel yaitu variabel bebas (eksogen), pendidikan kewirausahaan $(\mathrm{X})$. Variabel terikat (endogen), niat berwirausaha (Y). Dan varibel intervening, risk taking $(\mathrm{Z} 1)$, self efficacy $(\mathrm{Z} 2)$, proactiveness $(\mathrm{Z} 3)$.

Analisis data yang digunakan pada penelitian ini agar dapat mengetahui hasil penelitian akan diolah dengan menggunakan metode Struktural Equational ModellingPartial Least Square (SEM-PLS) dan Software yang digunakan adalah SmartPLS versi 3.0. Dalam penelitian ini menggunakan 2 model tahapan perhitungan PLS yaitu Outer Model (Model Pengukuran) dan Inner Model (Model Struktural). Analisa Outer Model dilakukan untuk memastikan bahwa pengukuran yang digunakan layak untuk dijadikan alat ukur (valid dan reliabel). Sedangkan analisa Inner Model dilakukan untuk memastikan bahwa model struktural yang dibentuk kuat dan akurat (Hussein, 2015). Pada variance based SEM ini selain bisa untuk pengujian dan pengembangan model, variance based SEM bisa untuk melakukan prediksi model. Untuk ukuran sampel juga tidak selalu besar. PLS dapat mengetahui hubungan antar variabel laten, Dengan menggunakan PLS pada penelitian ini, maka peneliti dapat menghitung variabel intervening secara langsung, karena dalam penelitian ini terdapat variabel intervening (Haryono, 2014). 
Tabel 1. Operasional Variabel

\begin{tabular}{|c|c|c|}
\hline Variabel & Indikator & Sumber \\
\hline \multirow[t]{3}{*}{$\begin{array}{l}\text { Pendidikan } \\
\text { kewirausaha } \\
\text { an }(\mathrm{X})\end{array}$} & $\begin{array}{l}\text { Pembelajaran Produk Kreatif } \\
\text { dan Kewirausahaan saya } \\
\text { mendorong kreativitas, } \\
\text { kemandirian dan inisiatif } \\
\text { pribadi }\end{array}$ & \multirow[t]{3}{*}{$\begin{array}{l}\text { (Ng et al., } \\
2019)\end{array}$} \\
\hline & $\begin{array}{l}\text { Pembelajaran Produk Kreatif } \\
\text { dan Kewirausahaan saya } \\
\text { memberikan instruksi yang } \\
\text { memadai di pasar prinsip } \\
\text { ekonomi }\end{array}$ & \\
\hline & $\begin{array}{l}\text { Pembelajaran Produk Kreatif } \\
\text { dan Kewirausahaan saya } \\
\text { memberikan perhatian yang } \\
\text { memadai untuk kewirausahaan } \\
\text { dan penciptaan usaha baru }\end{array}$ & \\
\hline \multirow[t]{5}{*}{$\begin{array}{c}\text { Niat } \\
\text { berwirausaha } \\
\text { (Y) }\end{array}$} & $\begin{array}{l}\text { Saya siap melakukan apa saja } \\
\text { untuk menjadi pengusaha }\end{array}$ & \multirow[t]{5}{*}{$\begin{array}{l}\text { (Tsordia \& } \\
\text { Papadimitr } \\
\text { iou, 2015) }\end{array}$} \\
\hline & $\begin{array}{l}\text { Tujuan profesional saya adalah } \\
\text { menjadi pengusaha }\end{array}$ & \\
\hline & $\begin{array}{l}\text { Saya akan melakukan segala } \\
\text { upaya untuk memulai dan } \\
\text { menjalankan perusahaan saya } \\
\text { sendiri }\end{array}$ & \\
\hline & $\begin{array}{l}\text { Saya bertekad untuk membuat } \\
\text { usaha bisnis di masa depan }\end{array}$ & \\
\hline & $\begin{array}{l}\text { Saya sangat serius berpikir } \\
\text { untuk memulai sebuah usaha }\end{array}$ & \\
\hline \multirow[t]{3}{*}{$\begin{array}{l}\text { Risk Taking } \\
\left(\mathrm{Z}_{1}\right)\end{array}$} & $\begin{array}{l}\text { Sebagai pemilik bisnis, saya } \\
\text { memiliki pilihan yang kuat } \\
\text { untuk risiko tinggi }\end{array}$ & \multirow[t]{3}{*}{$\begin{array}{l}\text { (Al } \\
\text { Mamun \& } \\
\text { Fazal, } \\
\text { 2018) }\end{array}$} \\
\hline & $\begin{array}{l}\text { Saya suka mengambil tindakan } \\
\text { berani dengan menjelajah ke } \\
\text { tempat yang tidak diketahui }\end{array}$ & \\
\hline & $\begin{array}{l}\text { Saya cenderung bertindak } \\
\text { "berani" dalam situasi yang } \\
\text { melibatkan risiko }\end{array}$ & \\
\hline \multirow[t]{6}{*}{$\begin{array}{l}\text { Self Efficacy } \\
\quad\left(\mathrm{Z}_{2}\right)\end{array}$} & $\begin{array}{l}\text { Saya dapat mengidentifikasi } \\
\text { kebutuhan akan produk atau } \\
\text { layanan baru }\end{array}$ & \multirow[t]{6}{*}{$\begin{array}{l}\text { (Kumar \& } \\
\text { Das, 2019) }\end{array}$} \\
\hline & $\begin{array}{l}\text { Saya dapat merancang produk } \\
\text { atau layanan yang akan } \\
\text { memuaskan kebutuhan dan } \\
\text { keinginan pelanggan }\end{array}$ & \\
\hline & $\begin{array}{l}\text { Saya yakin memperkirakan } \\
\text { permintaan pelanggan untuk } \\
\text { produk atau layanan baru saya }\end{array}$ & \\
\hline & $\begin{array}{l}\text { Saya dapat menjelaskan dengan } \\
\text { jelas dan ringkas secara lisan } \\
\text { atau tulisan mengenai ide bisnis } \\
\text { saya }\end{array}$ & \\
\hline & $\begin{array}{l}\text { Saya yakin bisa menemukan } \\
\text { ide baru untuk suatu produk } \\
\text { atau layanan }\end{array}$ & \\
\hline & $\begin{array}{l}\text { Saya bisa melakukan interaksi } \\
\text { dan bertukar informasi dengan } \\
\text { seseorang mengenai } \\
\text { kewirausahaan }\end{array}$ & \\
\hline \multirow[t]{4}{*}{$\begin{array}{c}\text { Proactiveness } \\
\left(\mathrm{Z}_{3}\right)\end{array}$} & $\begin{array}{l}\text { Jika saya melihat sesuatu yang } \\
\text { tidak saya sukai, saya } \\
\text { memperbaikinya }\end{array}$ & \multirow[t]{4}{*}{$\begin{array}{l}\text { (Delle \& } \\
\text { Amadu, } \\
\text { 2015) }\end{array}$} \\
\hline & $\begin{array}{l}\text { Tidak peduli apa } \\
\text { kemungkinannya, jika saya } \\
\text { percaya pada sesuatu, saya } \\
\text { akan berhasil }\end{array}$ & \\
\hline & $\begin{array}{l}\text { Saya selalu mencari cara yang } \\
\text { lebih baik untuk melakukan } \\
\text { sesuatu }\end{array}$ & \\
\hline & $\begin{array}{l}\text { Jika saya percaya pada } \\
\text { sebuah ide, tidak ada halangan }\end{array}$ & \\
\hline
\end{tabular}

yang akan menghalangi saya

untuk mewujudkannya

Saya bisa melihat peluang

bagus jauh sebelum orang lain bisa

Sumber : Penelitian (2021)

\section{HASIL DAN PEMBAHASAN \\ Deskripsi Responden}

Tabel 2. Demografi Responden

\begin{tabular}{llll}
\hline No & Kategori & $\begin{array}{l}\text { Frekuensi } \\
\text { (f) }\end{array}$ & Presentase \\
\hline 1. & Jenis Kelamin : & 12 & $6,4 \%$ \\
& Laki-laki & 176 & $93,6 \%$ \\
& Perempuan & 188 & $100 \%$ \\
& Total & & \\
2. & Usia : & 188 & $100 \%$ \\
& $\leq 18$ tahun & - & - \\
& 19-23 tahun & 188 & $100 \%$ \\
& Total & & \\
3. Pengalaman & & $22,9 \%$ \\
& Bisnis : & 43 & $77,1 \%$ \\
& Berpengalaman & 145 & $100 \%$ \\
\hline & Tidak & & \\
& berpengalaman & 188 & \\
& Total & &
\end{tabular}

Sumber : Data diolah (2021)

Berdasarkan tabel 2 mengenai deskripsi responden dapat diketahui bahwa jenis kelamin responden lebih banyak perempuan dengan jumlah 176 dengan presentase $93,6 \%$. Untuk kategori usia responden secara keseluruhan $\leq 18$ tahun yaitu 188 dengan presentase 100\%. Dan untuk kategori responden berdasarkan pengalaman bisnis lebih banyak yang belum berpengalaman yaitu sebesar 145 dengan presentase $77,1 \%$.

\section{Model Pengukuran (Outer Model)}

Penilaian outer model dalam analisis data dengan mengumpulkan seluruh data responden untuk di uji validitas dengan menggunakan Smart PLS dengan kriteria convergent validity dan discriminant validity, serta di uji reliabilitas dengan melalui composite reliability, cronbach alpha serta average variance extracted. Berikut merupakan tampilan output pada Smart PLS. 


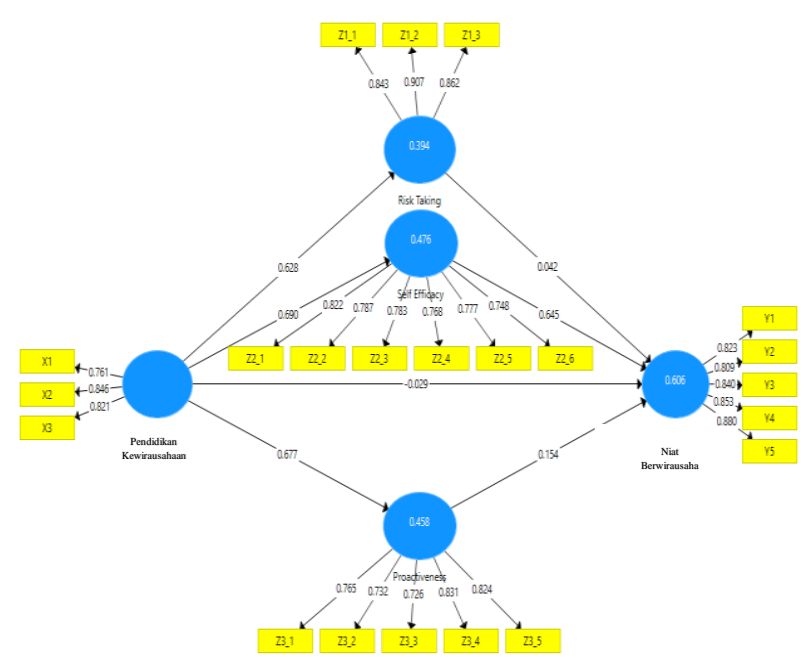

Gambar 2. Loading factor

Tabel 3. Cross Loading

\begin{tabular}{llllll}
\hline & PKW & NBW & $\begin{array}{l}\text { Risk } \\
\text { Taking }\end{array}$ & $\begin{array}{l}\text { Self } \\
\text { Efficacy }\end{array}$ & Proactiveness \\
\hline X1 & 0,761 & 0,385 & 0,409 & 0,529 & 0,473 \\
X2 & 0,846 & 0,419 & 0,598 & 0,597 & 0,633 \\
X3 & 0,821 & 0,524 & 0,502 & 0,548 & 0,527 \\
Y1 & 0,413 & 0,823 & 0,481 & 0,640 & 0,548 \\
Y2 & 0,446 & 0,809 & 0,524 & 0,616 & 0,493 \\
Y3 & 0,480 & 0,840 & 0,548 & 0,674 & 0,589 \\
Y4 & 0,446 & 0,853 & 0,478 & 0,639 & 0,545 \\
Y5 & 0,513 & 0,880 & 0,511 & 0,672 & 0,527 \\
Z1_1 & 0,559 & 0,502 & 0,843 & 0,624 & 0,533 \\
Z1_2 & 0,600 & 0,543 & 0,907 & 0,667 & 0,591 \\
Z1_3 & 0,474 & 0,535 & 0,862 & 0,651 & 0,585 \\
Z2_1 & 0,602 & 0,593 & 0,677 & 0,822 & 0,602 \\
Z2_2 & 0,510 & 0,672 & 0,557 & 0,787 & 0,547 \\
Z2_3 & 0,531 & 0,651 & 0,572 & 0,783 & 0,536 \\
Z2_4 & 0,534 & 0,557 & 0,531 & 0,768 & 0,622 \\
Z2_5 & 0,541 & 0,554 & 0,591 & 0,777 & 0,624 \\
Z2_6 & 0,514 & 0,582 & 0,551 & 0,748 & 0,569 \\
Z3_1 & 0,534 & 0,440 & 0,534 & 0,525 & 0,765 \\
Z3_2 & 0,440 & 0,516 & 0,415 & 0,551 & 0,732 \\
Z3_3 & 0,448 & 0,403 & 0,349 & 0,470 & 0,726 \\
Z3_4 & 0,575 & 0,515 & 0,507 & 0,608 & 0,831 \\
Z3_5 & 0,609 & 0,599 & 0,686 & 0,705 & 0,824 \\
\hline Sumber & $: D a t a$ & $019 h$ & $(2021)$ & &
\end{tabular}

Sumber : Data diolah (2021)

Mengukur uji validitas pada setiap item harus mendapatkan hasil nilai di atas 0,7 (Hair et al., 2014). Dilihat pada hasil loading factor dan cross loading, nilai pada setiap item berada diatas 0,7 , sehingga dapat dinyatakan bahwa data tersebut valid. Convergent validity juga dapat dilihat melalui Average Variance Extracted (AVE) dan dapat dinyatakan valid apabila setiap item mendapatkan nilai $\geq 0,5$ (Hair et al., 2014). Dapat dilihat pada tabel 1 AVE bahwa nilai setiap konstruk berada diatas 0,5 , sehingga dapat dikatakan validitas konvergen dinilai valid.
Tabel 4. Average Variance Extracted

\begin{tabular}{ll}
\hline Konstruk & AVE \\
\hline Pendidikan kewirausahaan & 0,656 \\
Niat berwirausaha & 0,708 \\
Risk Taking & 0,758 \\
Self Efficacy & 0,610 \\
Proactiveness & 0,604 \\
\hline
\end{tabular}

Sumber : Data diolah (2021)

Setelah melakukan pengujian Convergent validity, selanjutnya yaitu pengujian discriminant validity dengan cara perbandingan pada nilai cr akar kuadrat Average Variance Extracted dengan menggunakan nilai korelasi antar kontruk tersebut. Pada discriminant validity ini memiliki persyaratan yaitu akar kuadrat pada Average Variance Extracted (AVE) > nilai korelasi antar kontruk tersebut.

Tabel 5. Discriminant Validity

\begin{tabular}{lcccll}
\hline $\begin{array}{l}\text { Laten } \\
\text { Variable }\end{array}$ & PKW & NBW & $\begin{array}{l}\text { Proactiv } \\
\text { eness }\end{array}$ & $\begin{array}{l}\text { Risk } \\
\text { Taking }\end{array}$ & $\begin{array}{l}\text { Self } \\
\text { Efficacy }\end{array}$ \\
\hline PKW & 0,810 & & & & \\
NBW & 0,547 & 0,841 & & & \\
$\begin{array}{l}\text { Proactiven } \\
\text { ess }\end{array}$ & 0,677 & 0,643 & 0,777 & & \\
$\begin{array}{l}\text { Risk } \\
\text { Taking }\end{array}$ & 0,628 & 0,604 & 0,654 & 0,871 & \\
$\begin{array}{l}\text { Self } \\
\text { Efficacy }\end{array}$ & 0,690 & 0,771 & 0,745 & 0,743 & 0,781 \\
\hline
\end{tabular}

Sumber : Data diolah (2021)

Menurut dari kriteria Fornell \& Larcker (1981) dapat dijelaskan bahwa semua nilai pada akar kuadrat AVE harus lebih tinggi dibandingkan nilai korelasi yang menghubungkan setiap variabelnya, sehingga validitas diskriminan dapat menerima dan menganalisis lebih lanjut. Nilai pada akar kuadrat dari AVE harus lebih besar dari hubungan masing-masing setiap konstruk yaitu, Pendidikan kewirausahaan $(0,810>0,547 ; 0,677 ; 0,628$; $0,690)$; Niat berwirausaha $(0,817>0,547 ; 0,643 ; 0,604$; $0,771)$; Proactiveness $(0,777>0,677 ; 0,643 ; 0,654$; 0,745); Risk Taking $(0,871>0,628 ; 0,604 ; 0,654 ; 0,743)$; Self Efficacy $(0,781>0,690 ; 0,771 ; 0,745 ; 0,743)$.

Setelah melakukan pengujian Discriminant Validity dengan menggunakan nilai Fornell-Larcker Criterion. Tahap selanjutnya yaitu pengujian Discriminant Validity dengan menggunakan nilai Heterotrait-Monotrait Ratio (HTMT). Pada nilai HTMT untuk memastikan validitas diskriminan setiap konstruk reflektif, maka nilai HTMT harus $<0,9$ (Henseler et al., 2015). 
Tabel 6. Heterotrait-Monotrait Ratio (HTMT)

\begin{tabular}{lccccc}
\hline $\begin{array}{l}\text { Laten } \\
\text { Variable }\end{array}$ & PKW & NBW & $\begin{array}{l}\text { Proactiv } \\
\text { eness }\end{array}$ & $\begin{array}{l}\text { Risk } \\
\text { Taking }\end{array}$ & $\begin{array}{l}\text { Self } \\
\text { Efficacy }\end{array}$ \\
\hline PKW & & & & & \\
NBW & 0,671 & & & & \\
$\begin{array}{l}\text { Proactiven } \\
\text { ess }\end{array}$ & 0,848 & 0,735 & & & \\
$\begin{array}{l}\text { Risk } \\
\text { Taking } \\
\text { Self } \\
\text { Efficacy }\end{array}$ & 0,785 & 0,697 & 0,766 & & \\
\hline
\end{tabular}

Sumber : Data diolah (2021)

Tabel Heterotrait-Monotrait Ratio (HTMT) diatas memberikan hasil bahwa semua nila HTMT $<0,9$. Berdasarkan hasil tersebut maka dapat dinyatakan bahwa semua konstruk pada nilai HTMT valid secara validitas diskriminan berdasarkan perhitungan HTMT.

Tahap selanjutnya untuk pengujian outer model yaitu menguji unidimensionalitas dari model berdasarkan indikator pada composite reliability serta cronbach's alpha. Pada Nilai composite reliability serta cronbach's alpha harus $>0,7$.

Tabel 7. Composite Reliability

\begin{tabular}{lll}
\hline & Composite Reliability & Cronbach's Alpha \\
\hline $\begin{array}{l}\text { Pendidikan } \\
\text { Kewirausahaan }\end{array}$ & 0,851 & 0,738 \\
Niat & 0,924 & 0,897 \\
Berwirausaha & & \\
Risk Taking & 0,904 & 0,840 \\
Self Efficacy & 0,904 & 0,872 \\
Proactiveness & 0,884 & 0,836 \\
\hline
\end{tabular}

Sumber : Data diolah (2021)

Pada tabel 7 nilai composite reliability serta cronbach's alpha dari seluruh konstruk yaitu lebih dari 0,7. Sehingga tidak terdapat permasalahan pada reliabilitas/unidimensionalitas. Sehingga data pada penelitian ini dinyatakan valid serta reliabel.

\section{Model Pengukuran (Inner Model)}

Tahap pengujian inner model ini, cara yang dilakukan yaitu melalui 3 cara nilai $\mathrm{R}^{2}, \mathrm{Q}^{2}$, dan $G o F$. Tabel 8. R Square

\begin{tabular}{lll}
\hline & R Square & R Square Adjusted \\
\hline $\mathbf{Y}$ & 0,606 & 0,598 \\
$\mathbf{Z 1}$ & 0,394 & 0,391 \\
$\mathbf{Z 2}$ & 0,476 & 0,473 \\
$\mathbf{Z 3}$ & 0,458 & 0,455 \\
\hline
\end{tabular}

Sumber : Data diolah (2021)

Pengujian R Square ini digunakan untuk mengukur akurasi prediktif, nilai $\mathrm{Y}: 0,606, \mathrm{Z1}: 0,394, \mathrm{Z2}$ : 0,476, dan Z3 : 0,458. Nilai R Square pada tabel 8 memiliki arti yaitu pada variabel niat berwirausaha (Y) sebesar $60,6 \%$ dapat dipengaruhi oleh variabel bebas yang terdapat dalam penelitian ini, sedangkan nilai 39,4\% dapat dipengaruhi terhadap variabel bebas yang ada pada luar penelitian ini. Nilai pada variabel risk taking (Z1) memiliki nilai sebesar 39,4\% yang dapat dipengaruhi oleh pendidikan kewirausahaan $(\mathrm{X})$ dan niat berwirausaha $(\mathrm{Y})$, sedangkan nilai $60,6 \%$ dipengaruhi oleh variabel lain. Nilai variabel self efficacy (Z2) sebesar 47,6\% dipengaruhi oleh pendidikan kewirausahaan $(\mathrm{X})$ dan niat berwirausaha (Y), sedangkan nilai 52,6\% dapat dipengaruhi terhadap variabel bebas yang ada pada luar penelitian ini. Dan nilai variabel proactiveness (Z3) sebesar $45,8 \%$ dipengaruhi oleh pendidikan kewirausahaan (X) dan niat berwirausaha (Y), sedangkan nilai 54,2\% dipengaruhi oleh variabel lain. Pada tahap ini apabila $\mathrm{R}^{2}<0,5$ yaitu artinya memiliki variabel bebas yang relatif lemah terhadap variabel terikatnya. Dan sebaliknya apabila $\mathrm{R}^{2}>0,5$ artinya variabel bebas kuat terhadap variabel terikatnya (Hair et al., 2014).

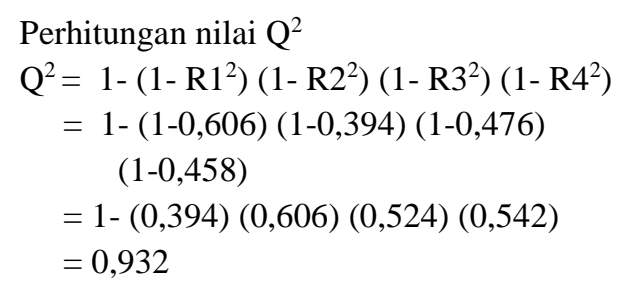

Menurut Hair et al. (2011) apabila nilai pada $\mathrm{Q}^{2}$ lebih besar dari nol maka nilai tersebut dapat dikatakan memiliki relevansi prediktif terhadap variabel endogen. Nilai $Q^{2}$ adalah 0,932, dapat dijelaskan bahwa nilai model struktural pada penelitian ini sebesar 93,2\% keberagaman data dalam penelitian ini, dan nilai $6,8 \%$ dapat dipengaruhi terhadap variabel bebas yang ada pada luar penelitian ini. Sedangkan nilai $G o F=\sqrt{A V E x R^{2}}$

$$
\begin{aligned}
& =\sqrt{0,668 \times 0,484} \\
& =0,569
\end{aligned}
$$

Nilai Goodness of Fit (GoF) pada penelitian ini yaitu sebesar 0,569, artinya model termasuk dalam kategori besar. Nilai $\mathrm{R}^{2}, \mathrm{Q}^{2}$, dan GoF dapat membentuk model robust. Nilai $\mathrm{R}^{2}, \mathrm{Q}^{2}$, serta GoF dapat dikatakan sangat baik apabila hasil nilainya >0,1 (Ali et al., 2017). Dari hasil perhitungan pada nilai tersebut, sehingga keputusan hipotesis dapat dilakukan.

\section{Pengujian Hipotesis}

Tahap pengujian hipotesis, dapat dilihat nilai $\mathrm{t}-$ statistic dan $\mathrm{p}$-value. Pada nilai t-statistic > 1,96 dan $\mathrm{p}$ value $<0,05$, sehingga hipotesis pada penelitian dapat dinyatakan mempunyai pengaruh positif dan signifikan. Akan tetapi sebaliknya apabila t-statistic $<1,96$ dan $\mathrm{p}$ - 
value > 0,05 maka hipotesis dinyatakan tidak ada pengaruh.

Tabel 9. Path Analysis

\begin{tabular}{llllll}
\hline $\begin{array}{l}\text { Hypothes } \\
\text { is path }\end{array}$ & $\begin{array}{l}\text { Original } \\
\text { sample }\end{array}$ & T statistic & P Values & Keterangan & $\begin{array}{l}\text { Keputus } \\
\text { an } \\
\text { hipotesis }\end{array}$ \\
\hline $\mathbf{X} \rightarrow \mathbf{Y}$ & 0,029 & 0,332 & 0,740 & $\begin{array}{l}\text { Tidak } \\
\text { signifikan }\end{array}$ & Ditolak \\
$\begin{array}{l}\mathbf{X} \rightarrow \mathbf{Z 1} \\
\rightarrow \mathbf{Y}\end{array}$ & 0,026 & 0,466 & 0,641 & $\begin{array}{l}\text { Tidak } \\
\text { signifikan }\end{array}$ & Ditolak \\
$\begin{array}{l}\mathbf{X} \rightarrow \mathbf{Z 2} \\
\rightarrow \mathbf{Y}\end{array}$ & 0,445 & 5,340 & 0,000 & $\begin{array}{l}\text { Signifikan } \\
\text { Diterima }\end{array}$ & Ditak \\
$\begin{array}{l}\mathbf{X} \rightarrow \mathbf{Z 3} \\
\rightarrow \mathbf{Y}\end{array}$ & 0,105 & 1,402 & 0,161 & $\begin{array}{l}\text { Tidak } \\
\text { signifikan }\end{array}$ & Ditolak \\
\hline
\end{tabular}

Sumber : Data diolah (2021)

\section{Pengaruh pendidikan kewirausahaan terhadap niat berwirausaha}

Pendidikan kewirausahaan tidak signifikan terhadap niat berwirausaha. Nilai variabel pendidikan kewirausahaan terhadap niat berwirausaha dengan koefisien jalur sebesar 0,029, t-statistic sebesar 0,332< 1,96 dan p-value 0,740>0,05, maka hipotesis pertama pada penelitian ini dapat dinyatakan ditolak atau tidak ada pengaruh secara signifikan antara pendidikan kewirausahaan terhadap niat berwirausaha pada masa pandemi covid-19. Berdasarkan hasil tersebut dapat dinyatakan bahwa siswa SMKN 1 Surabaya kelas XI dan XII hanya mengikuti pendidikan Produk Kreatif dan Kewirausahaan saja tanpa adanya niat berwirausaha pada diri siswa.

Berdasarkan hasil observasi di SMKN 1 Surabaya memberikan hasil bahwa kurikulum di SMKN 1 Surabaya terdapat pendidikan yang berorientasi pada kewirausahaan yaitu mata pelajaran produk kreatif dan kewirausahaan. Selama pandemi covid-19 mata pelajaran Produk Kreatif dan Kewirausahaan di SMKN 1 Surabaya sudah diterima siswa dengan baik. Mata pelajaran tersebut bertujuan untuk melatih siswa agar dapat berkreatif dalam membuat produk usaha sendiri untuk dijual. Sehingga lulusan SMKN 1 Surabaya mampu mencetak generasi yang memiliki jiwa wirausaha. Namun hal tersebut tidak selalu membuat siswa memiliki niat untuk berwirausaha. Dikarenakan siswa tidak berani untuk mencoba berwirausaha hanya karena adanya rasa takut gagal dalam berwirausaha. Masalah tersebut dapat diatasi apabila siswa mendapatkan sebuah pelatihan, ekstrakulikuler atau kegiatan lainnya mengenai wirausaha, sehingga siswa dapat memiliki pengalaman dalam berwirausaha. Dengan adanya pelatihan tersebut dapat menumbuhkan niat wirausaha pada diri siswa. Hasil penelitian ini terbalik dengan hasil penelitian Aryaningtyas \& Palupiningtyas (2017) yang mengungkapkan bahwa pendidikan kewirausahaan memberikan pengaruh yang positif dan signifikan terhadap niat berwirausaha. Hasil dari penelitian ini juga terbalik dengan hasil penelitian Abbassi \& Sta (2019) yang menunjukkan bahwa pendidikan kewirausahaan berpengaruh secara positif serta siginifikan terhadap niat berwirausaha. Penelitian ini berbeda dengan hasil penelitian terdahulu yang memberikan hasil bahwa pendidikan kewirausahaan memiliki pengaruh yang signifikan terhadap niat berwirausaha.

Akan tetapi, penelitian ini didukung oleh hasil penelitian Mahendra et al. (2017) yang menemukan hasil bahwa pendidikan kewirausahaan tidak secara langsung berpengaruh terhadap niat berwirausaha. Hasil penelitian ini juga didukung oleh penelitian Pratana \& Margunani (2019) bahwa pendidikan kewirausahaan tidak memberikan berpengaruh terhadap intensi berwirausaha kepada mahasiswa Pendidikan Ekonomi angkatan 2015 Universitas Negeri Semarang, dikarenakan mahasiswa dalam menempuh pendidikan kewirausahaan hanya sebagai kewajiban saja, sehingga tidak menumbuhkan intensi berwirausaha pada diri mahasiswa.

Hasil penelitian ini juga didukung oleh hasil penelitian Agusmiati \& Wahyudin (2019) yang memberikan hasil bahwa pendidikan kewirausahaan terdapat pengaruh negatif dan tidak signifikan terhadap minat berwirausaha siswa.

\section{Risk taking mampu memediasi hubungan antara pendidikan kewirausahaan terhadap niat berwirausaha \\ Risk taking sebagai variabel mediasi tidak} berpengaruh signifikan terhadap hubungan pendidikan kewirausahaan dan niat berwirausaha. Nilai variabel risk taking pada hubungan pendidikan kewirausahaan terhadap niat berwirausaha dengan koefisien jalur sebesar 0,026, tstatistic sebesar 0,466 < 1,96 dan p-value 0,641>0,05, maka hipotesis kedua pada penelitian ini dapat dinyatakan ditolak atau tidak ada pengaruh secara signifikan. Jadi risk taking tidak mampu memediasi pendidikan kewirausahaan dan niat berwirausaha pada masa pandemi covid-19. Berdasarkan hasil observasi di SMKN 1 Surabaya juga memberikan hasil bahwa siswa SMKN 1 Surabaya kelas XI dan XII selama pandemi covid-19 sudah mengikuti pendidikan produk kreatif dan kewirausahaan secara baik, namun hal tersebut tidak membuat siswa memiliki niat berwirausaha. Dikarenakan dalam berwirausaha cenderung melibatkan risiko. Risiko merupakan suatu proses yang penuh dengan ketidakpastian dan dapat menimbulkan sebuah kerugian, sehingga selama pademi covid-19 siswa tidak berani dalam pengambilan risiko untuk memulai berwirausaha. Untuk mengatasi hal tersebut, maka strategi yang dilakukan agar siswa berani dalam pengambilan risiko yaitu meningkatkan pelatihan mengenai wirausaha dengan cara melatih kreativitas pada diri siswa dengan membuat konsep suatu produk yang siap dijual. Dengan adanya hal tersebut siswa dapat memiliki pengalaman dalam berwirausaha dan berani dalam 
pengambilan risiko. Berdasarkan hasil tersebut bahwa risk taking sebagai mediasi tidak dapat mempengaruhi pendidikan kewirausahaan terhadap niat berwirausaha. Hasil penelitian ini terbalik dengan hasil penelitian Adu et al. (2020) yang menunjukkan bahwa risk taking sebagai mediasi mampu mempengaruhi hubungan antara pendidikan kewirausahaan dan niat berwirausaha.Hasil penelitian ini juga terbalik dengan hasil penelitian Gurel et al. (2010) yang mengungkapkan bahwa melalui risk taking maka pendidikan kewirausahaan berpengaruh positif terhadap niat berwirausaha

Namun, hasil penelitian ini sesuai pada penelitian Mustofa \& Ekawati (2017) yang menujukkan hasil bahwa pengambilan risiko sebagai variabel mediasi tidak ada pengaruh secara signifikan terhadap niat berwirausaha. Hasil penelitian ini juga didukung oleh penelitian Altinay et al. (2012) yang memberikan hasil bahwa pengambilan risiko terdapat pengaruh negatif terhadap niat berwirausaha.

\section{Self efficacy mampu memediasi hubungan antara pendidikan kewirausahaan terhadap niat berwirausaha}

Self efficacy sebagai variabel mediasi berpengaruh secara positif dan signifikan terhadap hubungan pendidikan kewirausahaan dan niat berwirausaha. Nilai variabel self efficacy pada hubungan pendidikan kewirausahaan terhadap niat berwirausaha dengan koefisien jalur sebesar 0,445, t-statistic sebesar $5,340>1,96$ dan p-value $0,000<0,05$, maka hipotesis ketiga pada penelitian ini dapat dinyatakan diterima atau ada pengaruh secara signifikan. Hasil tersebut menunjukkan bahwa self efficacy sebagai mediasi mempengaruhi pendidikan kewirausahaan dan niat berwirausaha selama pandemi covid-19. Siswa SMKN 1 Surabaya kelas XI dan XII selama pandemi covid-19 sudah mengikuti pembelajaran Produk Kreatif dan Kewirausahaan dengan baik, sehingga selama pandemi covid-19 saat ini siswa memiliki rasa percaya diri dalam berwirausaha. Berdasarkan hasil observasi juga memberikan hasil bahwa siswa SMKN 1 Surabaya sudah mengikuti mata pelajaran produk kreatif dan kewirausahaan dengan baik. Mata pelajaran tersebut bertujuan untuk melatih siswa agar dapat berkreatif dalam membuat produk usaha untuk dijual. Sehingga dengan hal tersebut siswa memiliki keyakinan diri dalam berwirausaha. Oleh karena itu maka siswa mampu menemukan ide baru untuk suatu produk yang akan digunakan untuk wirausaha. Berdasarkan hasil tersebut menujukkan bahwa self efficacy mampu memediasi hubungan antara pendidikan kewirausahaan terhadap niat berwirausaha. Dapat disimpulkan bahwa semakin tinggi tingkatan pada pendidikan kewirausahaan maka dapat meningkatkan pula niat berwirausaha apabila memiliki self efficacy yang tinggi, karena dalam pendidikan kewirausahaan tidak selalu membuat siswa memiliki niat berwirausaha, maka adanya self efficacy nantinya akan mendorong pendidikan kewirausahaan yang telah didapatkan oleh siswa tersebut dapat diterapkan untuk memulai berwirausaha.

Hasil pengujian hipotesis diatas, maka hasil tersebut didukung oleh penelitian Lestari \& Sukirman (2020) yang menunjukkan hasil bahwa self efficacy sebagai mediasi mampu mempengaruhi secara positif serta signifikan hubungan antara pendidikan kewirausahaan dan niat berwirausaha pada siswa. Dengan adanya self efficacy sebagai varabel intervening maka pendidikan kewirausahaan memiliki pengaruh yang positif serta signifikan hubungan antara pendidikan kewirausahaan dan niat berwirausaha (Anggraeni \& Nurcaya, 2016).

Hasil penelitian ini juga didukung pada penelitian Agusmiati \& Wahyudin (2019) dan Sudjarwo et al. (2019) yang memberikan hasil pada penelitiannya bahwa self efficacy memediasi hubungan secara signifikan pengaruh pendidikan kewirausahaan terhadap niat berwirausaha. Apiatun \& Prajanti (2019) dalam penelitiannya juga menunjukkan hasil bahwa self efficacy sebagai variabel mediasi memberikan bukti bahwa variabel tersebut memberikan pengaruh yang kuat terhadap pengetahuan kewirausahaan dan kesiapan berwirausaha pada diri siswa.

\section{Proactiveness mampu memediasi hubungan antara pendidikan kewirausahaan terhadap niat berwirausaha \\ Proactiveness sebagai variabel mediasi tidak} berpengaruh signifikan terhadap hubungan pendidikan kewirausahaan dan niat berwirausaha. Nilai variabel proactiveness pada hubungan pendidikan kewirausahaan terhadap niat berwirausaha dengan koefisien jalur sebesar 0,105 , t-statistic sebesar 1,402 < 1,96 dan p-value $0,161>$ 0,05 , maka hipotesis keempat pada penelitian ini dapat dinyatakan ditolak atau tidak ada pengaruh secara signifikan. Hasil tersebut menunjukkan bahwa proactiveness tidak mampu memediasi pendidikan kewirausahaan dan niat berwirausaha selama pandemi covid-19. Berdasarkan hasil observasi di SMKN 1 Surabaya juga memberikan hasil bahwa siswa SMKN 1 Surabaya kelas XI dan XII selama pandemi covid-19 sudah mengikuti pendidikan produk kreatif dan kewirausahaan secara baik, akan tetapi hal tersebut tidak membuat siswa memiliki niat berwirausaha. Selama pandemi covid-19 saat ini siswa belum mampu untuk mencari peluang usaha yang ada. Dikarenakan siswa belum memiliki pengalaman di dunia usaha, sehingga siswa belum bisa mencari sebuah peluang untuk memulai berwirausaha. Dalam berwirausaha sikap proaktif ini 
sangat penting dalam melakukan wirausaha, karena mampu mencari sebuah peluang yang ada. Oleh karena itu, diperlukan adanya pelatihan atau kegiatan lainnya yang berhubungan dengan wirausaha, agar siswa mempunyai pengalaman mengenai wirausaha, sehingga siswa dapat mencari sebuah peluang usaha. Berdasarkan hasil tersebut bahwa proactiveness sebagai mediasi tidak dapat mempengaruhi pendidikan kewirausahaan terhadap niat berwirausaha. Hasil penelitian ini terbalik dengan hasil penelitian Adu et al. (2020) yang menunjukkan hasil bahwa proactiveness sebagai mediasi mampu mempengaruhi hubungan antara pendidikan kewirausahaan dan niat berwirausaha. Akan tetapi, penelitian ini juga didukung pada penelitian Chipeta \& Surujlal (2017) yang memberikan hasil bahwa perilaku proactiveness tidak ada pengaruh secara signifikan terhadap niat berwirausaha.

\section{SIMPULAN}

Berdasakan hasil penelitian ini, maka dapat disimpulkan bahwa pendidikan kewirausahaan tidak berpengaruh secara signifikan terhadap niat berwirausaha selama pandemi covid-19, risk taking sebagai mediasi tidak memiliki pengaruh secara signifikan antara pendidikan kewirausahaan dan niat berwirausaha selama pandemi covid-19, self efficacy mampu memediasi secara signifikan pengaruh pendidikan kewirausahaan terhadap niat berwirausaha selama pandemi covid-19, proactiveness tidak mampu memediasi secara signifikan pengaruh pendidikan kewirausahaan terhadap niat berwirausaha selama pandemi covid-19.

Implikasi manajerial dalam penelitian ini yaitu dalam SMK pengalaman berwirausaha sangat diperlukan untuk meningkatkan pengalaman siswa. Adanya pendidikan kewirausahaan dapat meningkatkan keterampilan siswa dalam berwirausaha. Untuk meningkatkan niat berwirausaha pada diri siswa, hendaknya selama pandemi covid-19 saat ini pihak sekolah mampu memberikan pelatihan mengenai kewirausahaan diluar pembelajaran kelas, seperti kegiatan pelatihan, ekstrakulikuler, serta kegiatan lainnya yang dapat meningkatkan kompetensi pada diri siswa. Dengan adanya hal tersebut maka akan meningkatkan peran variabel mediasi yaitu risk taking, self efficacy, dan proactiveness pada diri siswa. Semakin tinggi tingkat pengalaman ataupun pelatihan pada diri siswa, maka akan semakin tinggi pula tingkat niat berwirausaha siswa.

Penelitian ini memiliki keterbatasan yaitu peneliti hanya meneliti variabel yang memberikan pengaruh terhadap niat berwirausaha, karena peneliti hanya meninjau pada variabel pendidikan kewirausahaan, serta hubungan yang memediasi antara pendidikan kewirausahaan terhadap niat berwirausaha, yaitu risk taking, self efficacy,dan proactiveness. Dan pada penelitian ini juga hanya meneliti siswa kelas XI dan XII pada jurusan Otomatisasi Tata Kelola Perkantoran, tidak meneliti semua jurusan yang ada di SMKN 1 Suarabaya.

\section{DAFTAR PUSTAKA}

Abbassi, R., \& Sta, N. (2019). The Effect of self-esteem, entrepreneurship education, and entrepreneurial tradition of the family on the entrepreneurial intention among students. Journal of Business and Management Research, 12, 235-245. www.knowledgejournals.com

Adnyana, I. G. L. A., \& Purnami, N. M. (2016). Pengaruh Pendidikan Kewirausahaan, Self Efficacy dan Locus of Control Pada Niat Berwirausaha. 5(2), 1160 1188.

Adu, I. N., Boakye, K. O., Suleman, A.-R., \& Bingab, B. B. B. (2020). Exploring the factors that mediate the relationship between entrepreneurial education and entrepreneurial intentions among undergraduate students in Ghana. Asia Pacific Journal of Innovation and Entrepreneurship, 14(2), 215-228. https://doi.org/10.1108/apjie-07-2019-0052

Agusmiati, D., \& Wahyudin, A. (2018). Pengaruh Lingkungan Keluarga, Pengetahuan Kewirausahaan, Kepribadian, Dan Motivasi, Terhadap Minat Berwirausaha Dengan Self Efficacy Sebagai Variabel Moderating. Economic Education Analysis Journal, 7(3), 878-893. https://doi.org/10.15294/eeaj.v7i3.28317

Al Habib, M., \& Rahyuda, I. (2015). Pengaruh Efikasi Diri, Kebutuhan Akan Prestasi Dan Keberanian Mengambil Risiko Terhadap Niat Berwirausaha Mahasiswa. E-Jurnal Manajemen Universitas Udayana, 4(9), 254673.

Al Mamun, A., \& Fazal, S. A. (2018). Effect of entrepreneurial orientation on competency and micro-enterprise performance. Asia Pacific Journal of Innovation and Entrepreneurship, 12(3), 379398. https://doi.org/10.1108/apjie-05-2018-0033

Ali, F., Hussain, K., Konar, R., \& Jeon, H. M. (2017). The Effect of Technical and Functional Quality on Guests' Perceived Hotel Service Quality and Satisfaction: A SEM-PLS Analysis. Journal of Quality Assurance in Hospitality and Tourism, 18(3), 354-378 https://doi.org/10.1080/1528008X.2016.1230037

Altinay, L., Madanoglu, M., Daniele, R., \& Lashley, C. (2012). International Journal of Hospitality Management The influence of family tradition and psychological traits on entrepreneurial intention. International Journal of Hospitality Management, $31(2)$, 489-499. https://doi.org/10.1016/j.ijhm.2011.07.007

Anggraeni, D., \& Nurcaya, I. (2016). Peran Efikasi Diri Dalam Memediasi Pengaruh Pendidikan Kewirausahaan Terhadap Niat Berwirausaha. EJurnal Manajemen Universitas Udayana, 5(4), 241653. 
Apiatun, R., \& Prajanti, S. D. W. (2019). Peran SelfEfficacy Sebagai Variabel Intervening Pengaruh Pengetahuan Kewirausahaan dan Pengalaman Prakerin Terhadap Kesiapan Berwirausaha. Economic Education Analysis Journal, 8 (3), 11631181. 10.15294/eeaj.v13i2.17051 https://doi.org/DOI:

Aryaningtyas, A. T., \& Palupiningtyas, D. (2017). Pengaruh Pendidikan Kewirausahaan dan Dukungan Akademik Terhadap Niat Kewirausahaan Mahasiswa (Studi Pada Mahasiswa STIEPARI Semarang). Jurnal Ilmiah Manajemen \& Bisnis, $18(2)$,

140. https://doi.org/10.30596/jimb.v18i2.1398

Aryaningtyas, A. T., \& Palupiningtyas, D. (2019). Pengaruh Kepribadian Proaktif Terhadap Intensi Kewirausahaan Mahasiswa: Pendidikan Kewirausahaan Sebagai Variabel Moderasi. Jurnal Manajemen, Strategi Bisnis dan Kewrausahaan, Vol. $13 \quad$ No, 15-25. https://doi.org/https://doi.org/10.24843/MATRIK:J MBK.2019.v13.i01.p02

Badan Pusat Statistik. (2021). Keadaan Angkatan Kerja di Indonesia Februari 2021.

Bergner, S., Auburger, J., \& Paleczek, D. (2021). The why and the how: A nexus on how opportunity, risk and personality affect entrepreneurial intention. Journal of Small Business Management, O0(00), 1-34. https://doi.org/10.1080/00472778.2021.1934849

Chipeta, E. M., \& Surujlal, J. (2017). Influence Of Attitude, Risk Taking Propensity And Proactive Personaity On Social Entrepreneurship Intentions. Polish Journal of Management Studies, 15(2), 2736. https://doi.org/10.17512/pjms.2017.15.2.03

Delle, E., \& Amadu, I. M. (2015). Proactive Personality And Entrepreneurial Intention: Employment Status And Student Level As Moderators. International Journal of Small Business and Entrepreneurship Research, Vol.3, No., 1-13.

Devi, E. A., \& Hadi, N. U. (2018). Pengaruh Pendidikan Kewirausahaan Dan Peran Orang Tua Terhadap Intensi Berwirausaha Mahasiswa STKIP PGRI Tulungagung. JPEK (Jurnal Pendidikan Ekonomi Dan Kewirausahaan), 2(1), 1. https://doi.org/10.29408/jpek.v2i1.712

Dogan, E. (2015). The Effect of Entrepreneurship Education on Entrepreneurial Leadership of University Students. Asia-Pacific Journal of Business Venturing and Entrepreneurship, 13(3), 59-69. https://doi.org/10.16972/apjbve.13.3.201806.59

Fornell, C., \& Larcker, D. (1981). Structural equation models with unobservable variables and measurement error: Algebra and statistics. Journal of marketing research. Advances Methods of Marketing Research, 18(3), 382-388.

Geubrina, R. Q., \& Megawati. (2019). Pengaruh Faktor Dukungan Universitas dan Kepribadian Proaktif Terhadap Intensi Berwirausaha Pada Mahasiswa S1 Fakultas Ekonomi dan Bisnis Universitas Syiah Kuala. Jurnal Ilmiah Mahasiswa Ekonomi
Manajemen, $\quad 4(1), \quad 1-28$. file:///C:/Users/anggirahmas/Downloads/1001922755-1-PB.pdf

Gurel, E., Altinay, L., \& Daniele, R. (2010). Tourism Students' Entrepreneurial Intentions. Annals of Tourism Research, 37(3), 646-669. https://doi.org/10.1016/j.annals.2009.12.003

Hair, J. F., Ringle, C. M., \& Sarstedt, M. (2011). PLSSEM: Indeed a silver bullet. Journal of Marketing Theory and Practice, 19(2), 139-152. https://doi.org/10.2753/MTP1069-6679190202

Hair, J. F., Sarstedt, M., Hopkins, L., \& Kuppelwieser, V. G. (2014). Partial least squares structural equation modeling (PLS-SEM): An emerging tool in business research. European Business Review, 26(2), 106121. https://doi.org/10.1108/EBR-10-2013-0128

Haryono, S. (2014). Mengenal Metode Structural Equation Modeling (SEM) untuk penelitian manajemen menggunakan AMOS. Jurnal Ekonomi Dan Bisnis STIE YPN Vol. VII No. 1 Oktober 2014, VII(1), 23-34.

Henseler, J., Ringle, C. M., \& Sarstedt, M. (2015). A new criterion for assessing discriminant validity in variance-based structural equation modeling. Journal of the Academy of Marketing Science, 43(1), 115-135. https://doi.org/10.1007/s11747-014-04038

Hermawan, K. A., \& Fitria, S. (2020). Analisis Pengaruh Kecenderungan Dalam Mengambil Risiko dan Pendidikan Kewirausahaan Terhadap Niat Berwirausaha Dengan Efikasi Diri Sebagai Varibel Mediasi. 9(2019), 1-9.

Hu, R., Wang, L., Zhang, W., \& Bin, P. (2018). Creativity, proactive personality, and entrepreneurial intention: The role of entrepreneurial alertness. Frontiers in Psychology, 9(JUN), 1-10. https://doi.org/10.3389/fpsyg.2018.00951

Hussein, A. S. (2015). Penelitian Bisnis dan Manajemen Menggunakan Partial Least Squares dengan SmartPLS 3.0. Universitas Brawijaya, 1, 1-19. https://doi.org/10.1023/A:1023202519395

Indriyani, R. (2017). Pengaruh Entrepreneurship Education Terhadap Entrepreneurial Intention Melalui Entrepreneurial Motivation Sebagai Mediasi Pada Mahasiswa Perguruan Tinggi Swasta Di Surabaya. BISMA (Bisnis Dan Manajemen), 10(2012), 26-46.

Keat, O. Y., Selvarajah, C., \& Meyer, D. (2011). Inclination towards entrepreneurship among university students: An empirical study of Malaysian university students. International Journal of Business and Social Science, 2(July 2015), 206-220. https://doi.org/10.1016/j.egypro.2012.02.331

Kumar, S., \& Das, S. (2019). An extended model of theory of planned behaviour: Entrepreneurial intention, regional institutional infrastructure and perceived gender discrimination in India. Journal of Entrepreneurship in Emerging Economies, 11(3), 369-391. https://doi.org/10.1108/JEEE-09-20180089 
Lekoko, M., E, M. R., \& P, R. (2012). The effectiveness of entrepreneurship education: What matters most? African Journal of Business Management, 6(51), 12023-12032. https://doi.org/10.5897/ajbmx12.001

Lestari, Y. P., \& Sukirman. (2020). Pengaruh Self Efficacy Sebagai Mediasi dari Pengaruh Kewirausahaan dan Lingkungan Keluarga terhadap Minat Berwirausaha. Economic Education Analysis, 2(9), 615-633. https://doi.org/10.15294/eeaj.v9i1.39469

Lumpkin, G. T., \& Dess, G. G. (1996). Clarifying the Entreprenuerial Orientation Construct and Linking it to Performance. Academy of Management Review, Vol. 21, N, 135-172.

Mahendra, A. M., Djatmika, E. T., \& Hermawan, A. (2017). The Effect of Entrepreneurship Education on Entrepreneurial Intention Mediated by Motivation and Attitude among Management Students, State University of Malang, Indonesia. International Education Studies, 10(9), 61. https://doi.org/10.5539/ies.v10n9p61

Mustofa, A. L. A., \& Ekawati, N. W. (2017). Keberanian Mengambil Risiko Memediasi Pengaruh Efikasi diri Dan Kebutuhan Akan Prestasi Terhadap Niat Berwirausaha. 6(10), 5377-5404. efikasi diri, kebutuhan akan prestasi, keberanian mengambil risiko, niat berwirausaha, path analysis.

Ng, H. S., Hung Kee, D. M., \& Khan, M. J. (2019). Effects of personality, education and opportunities on entrepreneurial intentions. Education and Training. https://doi.org/10.1108/ET-02-2019-0040

Otache, I., Umar, K., Audu, Y., \& Onalo, U. (2019). The effects of entrepreneurship education on students' entrepreneurial intentions: A longitudinal approach. Education and Training. https://doi.org/10.1108/ET-01-2019-0005

Pratana, N. K., \& Margunani. (2019). Pengaruh Sikap Berwirausaha, Norma Subjektif dan Pendidikan Kewirausahaan Terhadap Intensi Berwirausaha. Economic Education Analysis Journal, 8(2), 537. https://doi.org/10.15294/eeaj.v8i2.31489

Ranto, D. W. P. (2016). Pengaruh orientasi Kewirausahaan terhadap kinerja UMKM bidang kuliner di Yogyakarta. Jurnal Bisnis, Manajemen, Dan Akuntansi, III(2), 1-11.

Rasli, A., Khan, S. U. R., Malekifar, S., \& Jabeen, S. (2013). Factors affecting entrepreneurial intention among graduate students of Universitu Teknology Malaysia. International Journal of Business and Social Science, 4(2), 182-188.

Sudjarwo, R., Wahyudin, A., \& Sudarma, K. (2019). The Role of Self-Efficacy in Mediating the Effect of Entrepreneurial's Knowledge, Personality and Family Circles Against the Enterprise's Interest. Ketut Sudarma / Journal of Economic Education, $8(1)$, 67-74. http://journal.unnes.ac.id/sju/index.php/jeec

Sugiyono. (2017). Metode Penelitian Bisnis. Alfabeta.

Tsordia, C., \& Papadimitriou, D. (2015). The Role of Theory of Planned Behavior on Entrepreneurial Intention of Greek Business Students. International Journal of Synergy and Research, 4(1), 23. https://doi.org/10.17951/ijsr.2015.4.1.23

Venkatraman, N. (1989). Strategic Orientation of Business Enterprises: The Construct, Dimensionality, and Measurement. Management Science, 35(8), 942962. https://doi.org/10.1287/mnsc.35.8.942

Wardani, V. K., \& Nugraha, J. (2021). Pengaruh Pendidikan Kewirausahaan, Lingkungan Keluarga, Attitude Towards Entrepreneurship Terhadap Intensi Berwirausaha Melalui Self Efficacy. Jurnal Ekonomi Pendidikan Dan Kewirausahaan, Vol. 9 No., Hal 79-100. https://doi.org/DOI: 10.26740/jepk.v9n1.p79-100

Yasira, N., Mahmoodb, N., Juttc, A. A., (2020). How Can Entrepreneurial Self-Efficacy, Proactivity and Creativity Enhance Sustainable Recognition Opportunity? The Effect of Entrepreneurial Alertness Is to. Journal of Early, XXIX, 1004-1023. https://doi.org/10.24205/03276716.2020.1097

Zulkosky, K. (2009). Self-Efficacy: A Concept Analysis. Nursing Forum, 44(2), 93-102. https://doi.org/10.1111/j.1744-6198.2009.00132.x 